\title{
ON THE COMBINED USE OF HEARING AID AND SPEECH-READING
}

\author{
By \\ KENITI IHARA \\ From the Department of Oto-Rhino-Laryngology, School of Medicine, Tokyo \\ Medical and Dental University. (Director: Prof. S. Horiguti)
}

The purpose of this study is to explore to what extent those who wear hearing aid use speechreading for their communication and also relationship between speech-reading ability and the severity of hard of hearing. For this purpose the author attempted the discrimination test using 5-lists of 3-syllable words to 100 hearing-aided cases of the sensory-neural hard of hearing individuals.

The following are the five test situations employed.

1) Speech-reading alone (silent)

2) Unaided hearing alone

3) Aided hearing alone

4) Unaided combination (auditory and visual)

5) Aided combination (auditory and visual)

The results obtained are as follows:

1) $81 \%$ of the individuals under the tests sho- wed the effectiveness of the aided combination, which was remarkable in the crses with a hearing loss of between 71 and $80 \mathrm{~dB}$.

2) Among the educated in speech-reading, there were found some individuals who are not making satisfactory use of the auditory cue because of their over dependence upon the ability of speech-reading.

3) Even in the uneducated in speech-reading, the compensatory aquirement of its ability was seen, and their speech discrimination was performed preformed predominantly by the auditory cue for those with a hearing loss between $80 \mathrm{~dB}$ and by the visual cue for those with a loss exceeding this value.

4) The speech discrimination tests described here are believed to be useful for determining the application of a hearing aid to severe cases of the sensory-neural hard of hearing individuals.

\section{補聴器と読話の併用效果について}

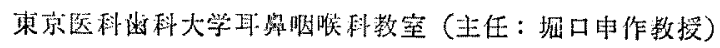

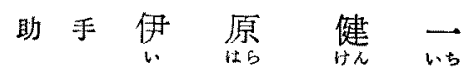

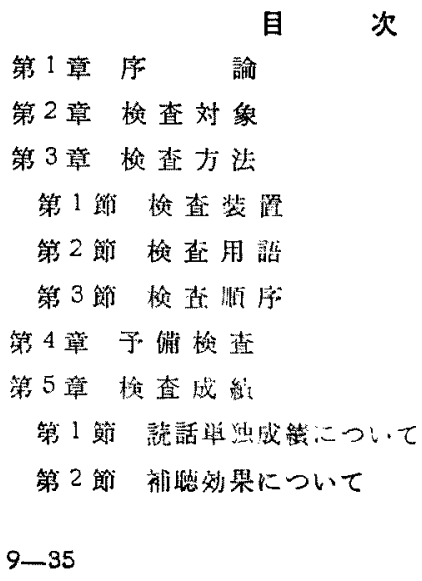

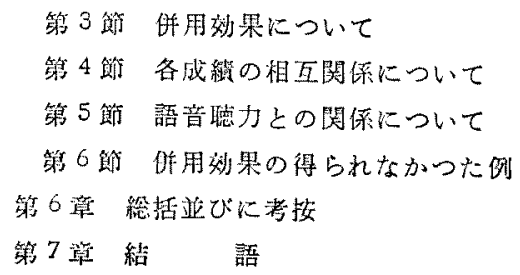

第 1 草 序論

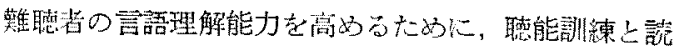

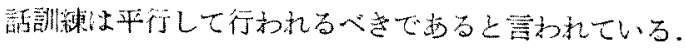

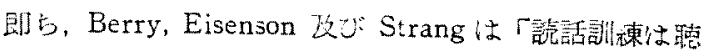
能訓練の中で取り上ゲられるべきである」と述べ、Pau・ 
1s は「読話の限界は補聴器の使用によつて, 補足する 渄ができる」と述べている。

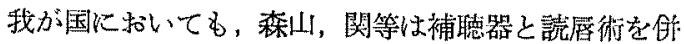
用して，著しい言語理解能力を得た症例を報告してお。 り，又，森本等の指導による新渴万ら教育研究会も，補 聴器の使用が口話教育の向上に有效である事を実駼的に 㯖付的ている。

しかし，こ机等心報告や研究は，単なる症例報告であ つたり，ろら教育の立場から行われた研究であるので， 䛃話と云う視覚的手捦りが，言語理解化果す役割の大き さや，それと残存聴力との関係，あるい、読話訓練を受 けたか否か炕よると差違等については明らかにされては いない.

我々は先きの研究に执いて，最良語音明瞭度が $50 \%$ に満たない難㯖者の大多数が, 補聴器を使用するに際し て, 読話を併用している事害を明らかにした。しかも， その難聴者の $80 \%$ が全く読話訓練を受けた 経験のない 人達である筆をも示した，従つて，読話訓練の経䀫の有

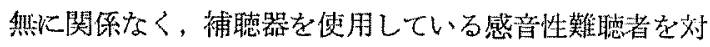
象とすれば，彼等が言語理解のために視覚的手掛りを， どの程度便网しているかを明らかにする㢦ができると考

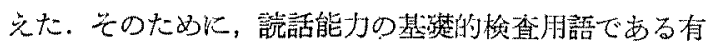
甞三節語を選定し，一表 25 語の 語音表 5 種を作製し た.この用語によつて, 読話単独, 裸耳単独, 補㯖耳

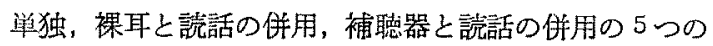
条件下に拈ける了解度を検査して，その成績を被険者の

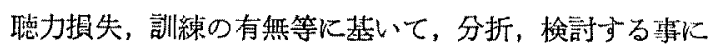
より興味ある成續を得る事ができた，又，この結果，徒 莱, 余り明らかにされていなかつた滈度難聴者の補聴器 適合判定についても一知見を得る束ができたので，ここ に報告する。

\section{第 2 章 検 查対象}

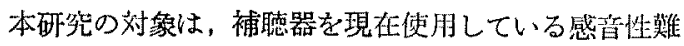
㖒者 100 名である. その純音聴力は $\frac{a+2 b+c}{4}$ 方式で $40 \mathrm{~dB}$ 以上の聰力損失を有する者ばかりで, 語音愉盉の 結果では0〜30\% の最良明膫度の範四に含ま机る。年令 は8 8 才り73 才に及び，平的22.4才であり，性别に見 る上罗 46 名女 54 名であつた。文刘象者帅に恃，知能障 留炎疑われる者は含まれていない。

読話能力は楌練を受けたか否かたよつて，大きな差遠 があると考えられるので，6力月以上，万ら教育起曼け

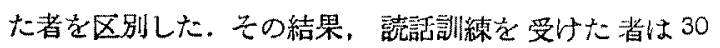

表 1 補璃器使用状洗

\begin{tabular}{ll} 
いっも使つている & 23 名 \\
特々使う & 39 \\
特别な場合たけ使う & 38 \\
\hline \multicolumn{1}{|c|}{} & 100 名
\end{tabular}

名、受けない省は70名となつた。この70名中家庭教師 等により，訬話訓練を受けた者は1人もなかつた。

蒱聴器の便用頻度を「いつを使つている」,「時々使つ ている」及び「特别の場合使用する」の三つに分類して 示すと（表1）の如くになる。「いつも使つている」と は，補聴器を終日使用している場合で，補聴器がすでに 耳の一部となつている状龍を云う。「時々使用する」は， 大体每日使用しているが，必要に応して使つたり，使わ なかつたりしている場合を云い、「特別な場合に使用す る」は面会，映画，講演等に際して時折使用する場合を 意味している. 更に, 各被検者共, 最底 3 カ月以上の䘯 聴器の使用渚である。

\section{第 3 章 検查方法}

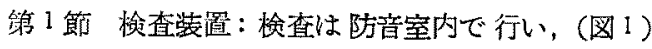

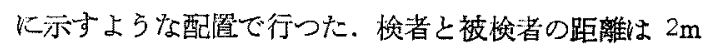
で，その中央にカーテンが妨り，必要に応じ開閉でき るようになつている，喤明は読話に影凃するので，充分 な明るさを保つた。

\section{四 1 检查装置}

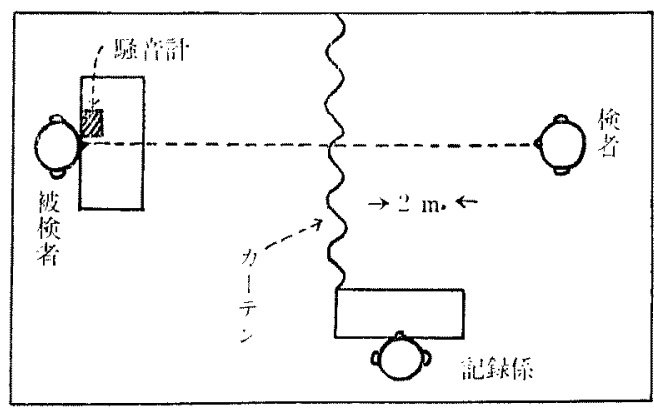

険者には，䌘潐語を話す女性を選び，声の大きさ，発 声，口型等を常に一定にしたままで話せるように練習せ しめた。特に, 声の大きさは, 被检者の左前方の机上に 㯰いた騒音計の日盛りが 65phon を越光ない上5に注 意せしめた。

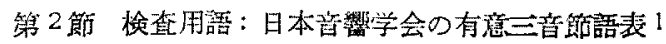
〜 5までの中から，坂本一郎䈞「教育基本語瀂」に基い 


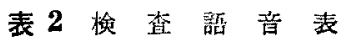

\begin{tabular}{|c|c|c|c|c|c|c|c|c|c|c|c|c|c|c|}
\hline \multicolumn{3}{|c|}{ 筑 一 } & \multicolumn{3}{|c|}{ 的二竞 } & \multicolumn{3}{|c|}{ 第 三 表 } & \multicolumn{3}{|c|}{ 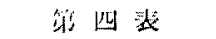 } & \multicolumn{3}{|c|}{ 第五 } \\
\hline あ & た & w & あ & $w$ & た & 出 & た & $る$ & あ & 才⿳े & $w$ & あ & $\%$ & く \\
\hline$d j$ & 5 & L & क & $る$ & $<$ & あ & わ & れ & क & $D$ & $w$ & 5 & L & b \\
\hline w & そ & く & 5 & $H$ & る & 5 & $\Sigma^{*}$ & ᄅ & W & た & $2 x$ & 之 & 5 & $\ddot{s}$ \\
\hline 5 & t & 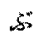 & 5 & क & さ & 50 & と & ts & 3 & 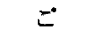 & $<$ & 出 & $\xi$ & $る$ \\
\hline 5 & わ & き & $5_{0}^{\circ}$ & $-z$ & 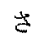 & $5^{\circ}$ & દ 5 & $\varepsilon$ & 无 & 5 & W & $b^{2}$ & た & る \\
\hline to & $\varepsilon$ & $=$ & s. & ż & ? & 加 & W $L$ & $p$ & 枋 & $\xi$ & $\eta$ & מ & る & w \\
\hline 掊 & - き & W & מ & ん L & $る$ & th & $\eta$ & る & $\$$ & ろ & t & き & $\infty$ & $z$ \\
\hline 坣 & ざ & ts & き & せ & 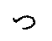 & מ & ん & $<$ & מ & $た$ & $b$ & $け$ & 才̃ & る \\
\hline 7 & リ - & 么 & $?$ & 西 & ま & $こ$ & の & $2 x$ & s & 5 & た & $た$ & 上 & る \\
\hline$=$ & と & ば & $H$ & いさ & 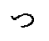 & $\Xi$ & 5 か & W & $<$ & ろ & $w$ & た & W & 5 \\
\hline た & מ & $w$ & $=$ & ど & 6 & た & 8 & $D$ & $\Sigma$ & よ. & 2 & $\varepsilon$ & ち & る \\
\hline た & ま & $\Xi$ & $\overleftrightarrow{d}$ & Wb & 5 & દ゙ & $b 5$ & $<$ & $た$ & た & $<$ & $ひ ゙$ & $つ た$ & $b$ \\
\hline$\varepsilon$ & $\not i$ & る & d & $w$ & $\Xi$ & $D$ & $<$ & $\overrightarrow{2}$ & た & 5 & D & L & ば & w \\
\hline$x^{2}$ & い. & え & L & $た$ & $<$ & 2 & よ & $w$ & $\varepsilon$ & 50 & $?$ & t & ぎ & 3 \\
\hline$\overline{7}$ & ヂ & $t$ & L & ろ & w & $\ddot{L}$ & $\check{E} \zeta \mathrm{L}$ & $p$ & ぼ & 儿 & $\eta$ & $\pi$ & 力 - & F \\
\hline L & え せ & $D$ & L & んば & $w$ & d & わ & ぐ & さ & W L & 上 & せ & ま & $\omega$ \\
\hline 5 & わ & る & 世 & か & $w$ & L & D & $け$ & $s$ & れ & る & せ & ん ば & $w$ \\
\hline は & な & t & $ひ$ & $た$ & $\eta$ & L & $つ$ れ & $w$ & す & $\not j 5$ & た & は & $こ$ & $S$ \\
\hline 5 & 力 & $w$ & .5 & ta & $\rightleftarrows$ & は & $p$ & $w$ & 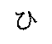 & と & 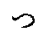 & 5 & L & ぎ \\
\hline 涯 & $\phi$ & 3 & $ま$ & b & 3 & $d$ & $\varepsilon$ & $w$ & 5 & $<$ & $b$ & 汪 & た & る \\
\hline 承 & 12 & $<$ & 次 & $\dot{\varepsilon}$ & ) & 专 & 上 & 5 & へ & $-\pi$ & $w$ & 6 & 5 & 5 \\
\hline 屯 & $\dot{x}$ & る & な & 45 & $\phi$ & 2 & $\$$ & $\varepsilon$ & は & つ & 门) & な & ts & d \\
\hline 12 & 机 & $z$ & $\omega$ & 涪 & 石 & $a$ & - b & $<$ & 恋 & $z$ & $w$ & 㲎 & む & 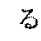 \\
\hline W & た & מ. & $p$ & 5 & 3 & 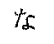 & 素 & 之 & $な$ & み & $t$ & わ & t & z \\
\hline & $<$ & 占 & $W$ & $D<$ & b) & p & さ & $w$ & $p$ & 5 & W & $p$ & $す$ & 七 \\
\hline
\end{tabular}

て, 小学校 3 年生程度の学犯で理解できる125 語を選完

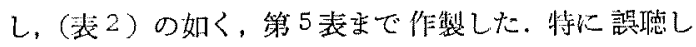
やすいもの，同音異語等を除外し，後述の予備桱侐に示

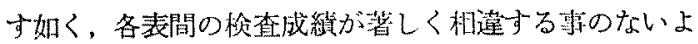
らに，語の配置を多少修正した。

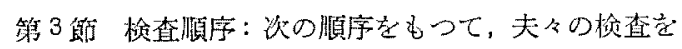
施行した。

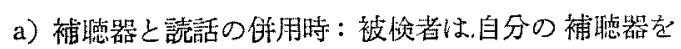
日常装朋している状態で保持し，予め検者の声が最も閏 きやすい音量に調整せしめた，又，読話が確尖にできる ように娭者の顔を正視するよう，注意を与えた。この检

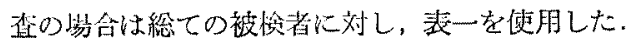

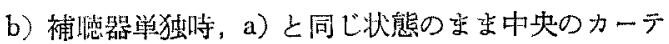

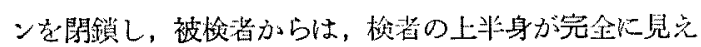

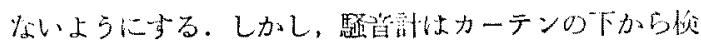
涽に見えるようにしてする。この惨查には䒾2を使用し た.

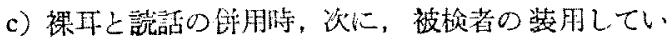
た補㯖器とカーテンを取り除き，表るによつて顺查を行
つた.

d) 裸耳単独時，c）の煌合のまをで，中央のカーテン

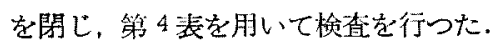

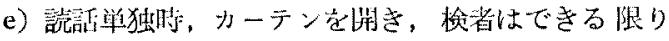

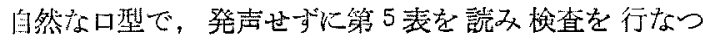
た.

表 3 併用检查成絽表 地名 年令—才失槙年命—才

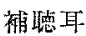
学校

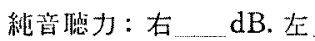

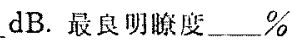

\begin{tabular}{|c|c|c|c|c|c|c|}
\hline 杭 & 高 & 項 & & 成 & 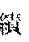 & $\%$ \\
\hline 雍 & 話 & 览 & 邰! & & & \\
\hline \multirow{2}{*}{\multicolumn{2}{|c|}{ 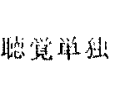 }} & 非 能 & 聴 & \multirow{2}{*}{$\cdots \cdots$} & \multirow{2}{*}{$\cdots$} & \\
\hline & & 袡 & 鯰 & & & \\
\hline \multirow{2}{*}{ 护 } & \multirow{2}{*}{ 用 } & 非 補 & 聴 & & & \\
\hline & & 枓 & 恐 & & & \\
\hline
\end{tabular}


以上の方法と順序は，総ての被検者に共通した方洗で あり，その応答は原則としてロ答とした。しかし，発語 の不明瞭なものは篗答により確認した。そん際用語の梳 みは1 1 回を原則とし，正しい答えに近いが疑わしい場合 のみ2回まで繰り返えした。記録保は正しい答を百分率 で採点し（表 3），の如き成績表に記録した。

\section{第 4 章 予備検查}

便用した語音表は，各被検者に対し，同一の順序で娭 查を行うので，同一条件下に抬ける夫々の被检者の成績 を相互に比較する事は可能である。しかし，異る検查条 件の成緽を相互に比較するためには，同一の条件下に拉 ける検查成績が各表共常に一定でなければならないと考 えられる、そのために各表間の読話され易い語，㯖き取 り易い語の配圆を充分に検討する事によつて，難易の差 をできる限り少くした．かくして作られた語音表を予備 険想により再娭討した，単に語の順序を翌える事によつ て，5つの表を作つたのでは，記憶によつて，後に行わ れる検査汪よ゙成績がよくなる危険性が考劣られたので, 各裴上も，全く異つた語を使用した。

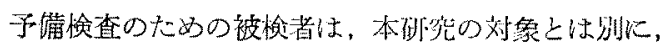
視力正常な補聴器使用者を選えだ. 枪楂の力法は前述の ものと大体同じであるが，1 回の梌查に 5 人を 1 組とし

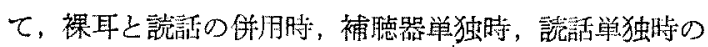
3つの条件についてのみ检楂した。応答は全部筆答で行

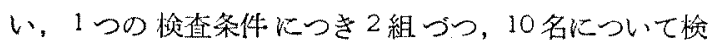
查を行つた，その結果は（表 4 ）に示した吙くでする。

表 4 予備梌查成制表 $(\%)$

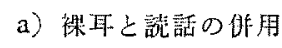

\begin{tabular}{|c|c|c|c|c|c|c|c|c|c|}
\hline \multicolumn{2}{|c|}{ 氏名 } & \multirow{2}{*}{\multicolumn{2}{|c|}{ 俨力攅失 }} & \multirow{2}{*}{ I.Q. } & \multirow{2}{*}{ 第1婊 } & \multirow{2}{*}{ 第2, 表 } & \multirow{2}{*}{ 第3第 } & \multirow{2}{*}{ 第4韭 } & \multirow{2}{*}{ 第5洨 } \\
\hline & & & & & & & & & \\
\hline U, & $\mathrm{U}$ & 58 & 44 & 76 & 96 & 100 & 96 & 96 & 92 \\
\hline $\mathrm{K}$, & $N$ & 55 & 64 & 74 & 36 & 48 & 44 & 44 & 36 \\
\hline $\mathrm{T}$, & A & 40 & 44 & 75 & 96 & 96 & 92 & 100 & 92 \\
\hline $\mathrm{K}$, & $\mathrm{K}$ & 74 & 75 & 66 & 36 & 32 & 40 & 36 & 32 \\
\hline M, & $\mathrm{H}$ & 74 & 65 & 85 & 40 & 48 & 44 & 40 & 36 \\
\hline Y, & B & 89 & 69 & 75 & 64 & 56 & 48 & 56 & 60 \\
\hline A, & $T$ & 86 & 68 & 73 & 16 & 16 & 20 & 20 & 16 \\
\hline Ir. & $S$ & 42 & 30 & 55 & 80 & 76 & 88 & 84 & 80 \\
\hline Y, & $\mathrm{Y}$ & 69 & 68 & 96 & 52 & 60 & 56 & 52 & 56 \\
\hline S, & $\mathrm{K}$ & 31 & 79 & 75 & 28 & 82 & 24 & 24 & 28 \\
\hline & & 要 & & & 544 & 564 & 552 & 552 & 528 \\
\hline
\end{tabular}

b) 補㯖器単独

\begin{tabular}{|c|c|c|c|c|c|c|c|c|c|}
\hline \multirow{2}{*}{ 氐 } & \multirow{2}{*}{ 名 } & \multicolumn{2}{|c|}{ 聴力損失 } & \multirow{2}{*}{ I.Q. } & \multirow{2}{*}{ 第l表 } & \multirow{2}{*}{ 第2裴 } & \multirow{2}{*}{ 第3武 } & \multirow{2}{*}{ 籁4裁 } & \multirow{2}{*}{ 第, 5 㳖 } \\
\hline & & 右 & 左 & & & & & & \\
\hline $\mathrm{M}$, & $Y$ & 65 & 73 & 61 & 72 & 72 & 80 & 68 & 64 \\
\hline $\mathrm{M}$, & M & 73 & 77 & 88 & 24 & 28 & 24 & 20 & 24 \\
\hline $\mathrm{S}$, & $\mathrm{K}$ & 74 & 79 & 75 & 28 & 36 & 32 & 44 & 40 \\
\hline $\mathrm{S}$, & I & 64 & 90 & 88 & 36 & 28 & 28 & 28 & 32 \\
\hline $\mathrm{K}$ & $\mathrm{K}$ & 69 & 81 & 78 & 60 & 56 & 64 & 60 & 64 \\
\hline $\mathrm{T}$ & $\mathrm{K}$ & 86 & 90 & 106 & 40 & 32 & 36 & 40 & 36 \\
\hline $\mathbf{J}$ & $\mathrm{S}$ & 80 & 55 & 82 & 80 & 76 & 72 & 76 & 72 \\
\hline $\mathrm{M}$, & $\mathrm{N}$ & 70 & 83 & 88 & 44 & 40 & 36 & 40 & 36 \\
\hline $\mathrm{K}$, & $\mathrm{K}$ & 74 & 75 & 66 & 92 & 96 & 100 & 92 & 96 \\
\hline $\mathrm{K}$ & $\mathrm{S}$ & 42 & 30 & 55 & 80 & 84 & 80 & 76 & 72 \\
\hline & & 訫 & & & 556 & 548 & 660 & 544 & 536 \\
\hline
\end{tabular}

c) 読話単独

\begin{tabular}{|c|c|c|c|c|c|c|c|c|c|}
\hline \multirow{2}{*}{ 氏 } & \multirow{2}{*}{ 名 } & \multicolumn{2}{|c|}{ 珤力鼬从 } & \multirow{2}{*}{ I.Q. } & \multirow{2}{*}{ 啝1教 } & \multirow{2}{*}{ 第2表 } & \multirow{2}{*}{ 第 4 裴 } & \multirow{2}{*}{ 第4 表 } & \multirow{2}{*}{ 第5 } \\
\hline & & 在 & 左 & & & & & & \\
\hline $\mathrm{N}$ & $\mathrm{H}$ & 63 & 68 & 74 & 36 & 32 & 36 & 28 & 32 \\
\hline $\mathrm{H}$ & $\mathrm{T}$ & 63 & 90 & 109 & 36 & 36 & 44 & 36 & 40 \\
\hline $\mathbf{J}$ & $\mathrm{S}$ & 80 & 55 & 82 & 32 & 32 & 36 & 28 & 30 \\
\hline $\mathrm{K}$, & I & 60 & 88 & 63 & 44 & 48 & 48 & 52 & 56 \\
\hline $\mathrm{M}$, & $\mathrm{M}$ & 73 & 77 & 88 & 36 & 24 & 36 & 28 & 24 \\
\hline $\mathrm{S}$, & $\mathrm{K}$ & 74 & 79 & 75 & 44 & 40 & 44 & 36 & 40 \\
\hline $\mathrm{S}$, & I & 64 & 90 & 88 & 60 & 52 & 60 & 64 & 48 \\
\hline $\mathrm{K}$, & $\mathrm{K}$ & 69 & 81 & 78 & 60 & 60 & 64 & 56 & 52 \\
\hline $\mathrm{T}$, & $\mathrm{K}$ & 86 & 90 & 106 & 32 & 28 & 28 & 28 & 32 \\
\hline $\mathrm{K}$ & $\mathrm{S}$ & 42 & 30 & 55 & 48 & 44 & 40 & 44 & 40 \\
\hline & & 訫 & & & 428 & 396 & 436 & 400 & 400 \\
\hline
\end{tabular}

この表に見られる如く，同一の検查条件下に括りる10

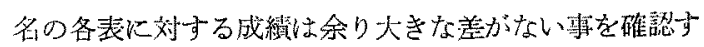
る排がでさ。

\section{第5 章 検査成綪}

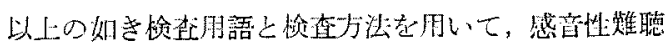

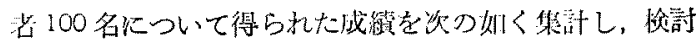
した.

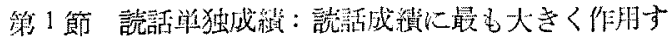

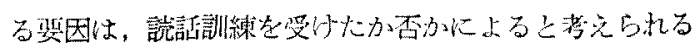

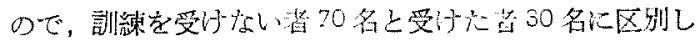

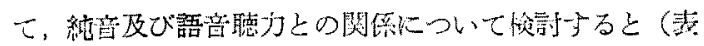
5，表6)の如くになる。 


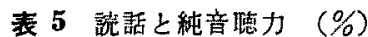

\begin{tabular}{|c|c|c|c|c|c|c|}
\hline 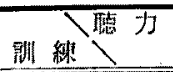 & $\begin{array}{l}40 \sim \mathrm{d} \\
50 \mathrm{db}\end{array}$ & $60 \mathrm{db}$ & $7 \mathrm{O} \widetilde{\mathrm{db}}$ & $8 \widetilde{71}$ & $81 \sim$ & $91 \mathrm{db}^{\text {汉昫 }}$ \\
\hline 受けていない & 13.8 & 18.8 & 18.8 & 23.0 & 27.5 & 16.020 .0 \\
\hline 受けた & . & 56.0 & 47.5 & 46.2 & 46.5 & -48.3 \\
\hline
\end{tabular}

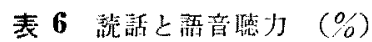

\begin{tabular}{|c|c|c|c|c|c|}
\hline 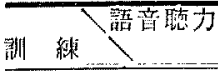 & $\begin{array}{r}0 \sim 25 ! \\
0 \\
0\end{array}$ & $\begin{array}{r}6 \sim 50 \\
\%\end{array}$ & $\begin{array}{r}1 \sim 75 \\
0 \\
1 \sim 0\end{array}$ & $\begin{array}{r}\sim 76 \\
\% \\
\end{array}$ & जI \\
\hline 曼けていない & 21.8 & 24.0 & 20.4 & 17.8 & 20.0 \\
\hline 受けた & 45.5 & 46.0 & 52.8 & - & 48.3 \\
\hline
\end{tabular}

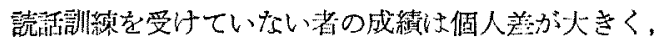

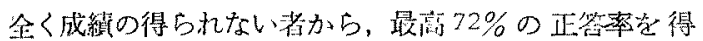

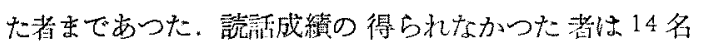

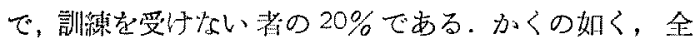

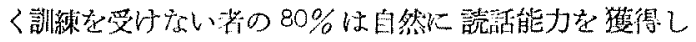

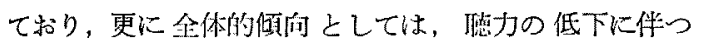
て、塄話成縝がよくなる㥧问が見られた。しかし，91 $\mathrm{dB}$ 以上の聴力損失者では，再び読話成維低下してい 万。

垲話訓練を受けた者では，成續の得られなかつた者は 呿らず, 最底 $8 \%$ から最高 $88 \%$ までの成筫が得られた

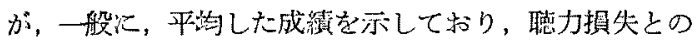

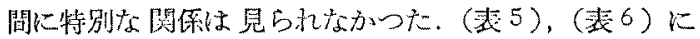
示した加く，全体の平枃值では，訓練を受けた者は受け ない者の約 2.4 倍の良い成狽を西した。

更に，誢話成績を失恥年令及び現在年令について調へ ると（表7)，(表 8) の如く，失聴年令の高い教ほど， 及び現在年令の高い者ほと，低い成績となつている，特 に50才以上の高令者では，読話成績は殆えど得られな い者が多かつた。

変 7 蔛話と失聴年令 $(\%)$

\begin{tabular}{|c|c|c|c|c|c|c|}
\hline & 令 㯖 & 力 & $\begin{array}{r}40 \sim 60 \\
\mathrm{db} \\
\end{array}$ & $\begin{array}{r}61 \sim 80 \\
\mathrm{db}\end{array}$ & ${ }^{81 \sim} \mathrm{db}$ & 平 均 \\
\hline 0 & $\sim 6$ & & 27.0 & 43.7 & 38.0 & 36.3 \\
\hline 7 & $\sim 20$ & 才 & 21.6 & 10.0 & 28.3 & 19.9 \\
\hline 21 & 才 以 & 上 & 9.4 & 6.0 & 28.0 & 14.4 \\
\hline
\end{tabular}

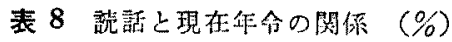

\begin{tabular}{|c|c|c|c|c|c|c|}
\hline 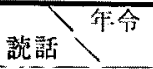 & $\begin{array}{r}8 \sim 10 \\
7\end{array}$ & $\begin{array}{r}1 \sim 15 \\
-7\end{array}$ & $\begin{array}{r}16 \sim 20 \\
\quad y\end{array}$ & $\begin{array}{r}1 \sim 30 \\
y\end{array}$ & $\begin{array}{r}31 \sim 50 \\
-7\end{array}$ & $0 \sim$ \\
\hline 平 均 值 & 31.0 & 38.1 & 33.1 & 29.3 & 15.3 & 3.3 \\
\hline
\end{tabular}

第2艒 補聴効果について

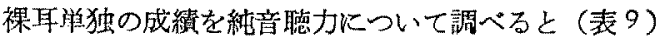
に示した通りである。これに対して，䋠聴器索便用し， 視紗を全く使用しない場合の成維は（表10）に示した

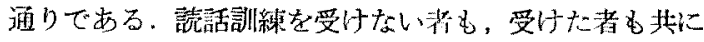
是い補媤效果を得ている牙が明らかであるが，読話訓練

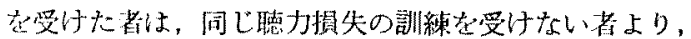

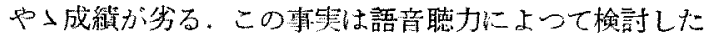
(翡11) に和いても見られる。

表 9 裸耳と純搵聴力 $(\%)$

\begin{tabular}{|c|c|c|c|c|c|c|c|}
\hline 部 & $50 \mathrm{db}$ & $60 \mathrm{db}$ & $70 \mathrm{db}$ & $80 \mathrm{db}$ & $90 \mathrm{db}$ & $\mathrm{db}$ & \\
\hline 罗け七い/5い & 24.0 & $9.8 !$ & $8.2^{\prime}$ & 0 & 0 & 8.5 & 8.5 \\
\hline 受けた & - & 5,6 & 2,5 & 0 & 0 & 3.7 & 3.7 \\
\hline
\end{tabular}

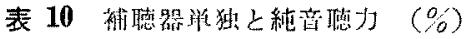

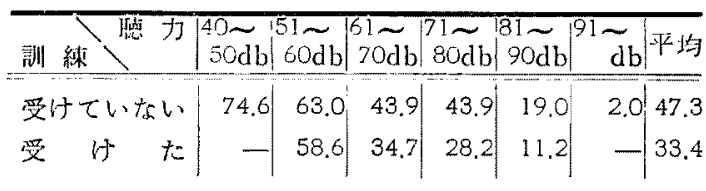

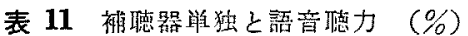

\begin{tabular}{|c|c|c|c|c|c|}
\hline 期1 維 & $\begin{array}{r}0 \sim 25 \\
\% \\
\end{array}$ & $\begin{array}{r}505 \\
\% \\
\end{array}$ & $\begin{array}{r}75 \\
\% \\
\end{array}$ & $\%$ & FF \\
\hline 受けてい炊い & 11.0 & 45.4 & 64.5 & 72.0 & 47.3 \\
\hline $\begin{array}{lll} & * & 6\end{array}$ & 13.3 & 42.8 & 46.0 & - & 33.4 \\
\hline
\end{tabular}

第了僻网成䋶について

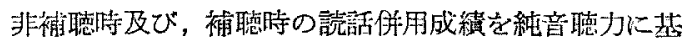
いて 集計すると（表 12），(表13）の如くなる，先つ （丧12）に見る如く，読話訓料を受けた者は，受けない

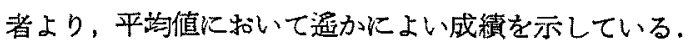
しかし，聴力椇失 81〜90dB の若では，画者殆んど同 じ成績である。次に，補㯖時の伊用成續を示した（表 13）を見るに，平均值では，訓練を受けた者る，受けな い者も同じ $73.3 \%$ の成縝を示している．しかし（表 12） と（䋤 13）を比較すると，訓練を受けなかつた者は，

表 12 裸耳と裞話の详用 $(\%)$

\begin{tabular}{|c|c|c|c|c|c|c|c|}
\hline 测 練 & $50 \sim \mathrm{db}$ & $51 \sim$ & $70 \mathrm{db}$ & $81 \widetilde{d}$ & & $\mathrm{db}$ & \\
\hline 受怕てい放い & 62.5 & 37.2 & 34.4 & 34,7 & 42.2 & 14.0 & \\
\hline 受 け た & & 61.3 & 56.7 & 56.9 & 41.0 & & \\
\hline
\end{tabular}


表 13 補聴器之読話の併用 (\%)

\begin{tabular}{|c|c|c|c|c|c|c|c|}
\hline 訓練入恥力 & $50 \widetilde{d b}$ & $60 \mathrm{db}]^{6}$ & $70 \mathrm{db}$ & $81 \widetilde{\mathrm{db}}$ & $90 \mathrm{db}$ & $\mathrm{dib}^{91} \tilde{\mathrm{d}}^{\mathrm{z}}$ & $\left.\right|^{\top 5}$ \\
\hline 受けてい & 87.6 & 76.0 & 70.1 & 78.5 & 60.5 & & 73.3 \\
\hline 受けた & & 85.7 & 68.9 & 77.4 & 51.0 & & 73.3 \\
\hline
\end{tabular}

裸耳と読話の併用の場合， $38.4 \%$ の平蚐值しか得られて いないのに，訓練を受けな者では，51.4\%の平均値を示 しており, 補聴器の使用による, 成積の改善度は, 遥か に，訓練を受けていない者の方が良い事になる。

第 4 節 各検查成績の相互関係について

以上，5種の検查成績を，読話訓練を受けた者と受け

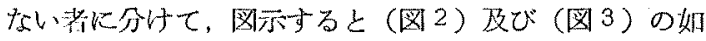
くになる。

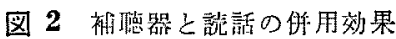

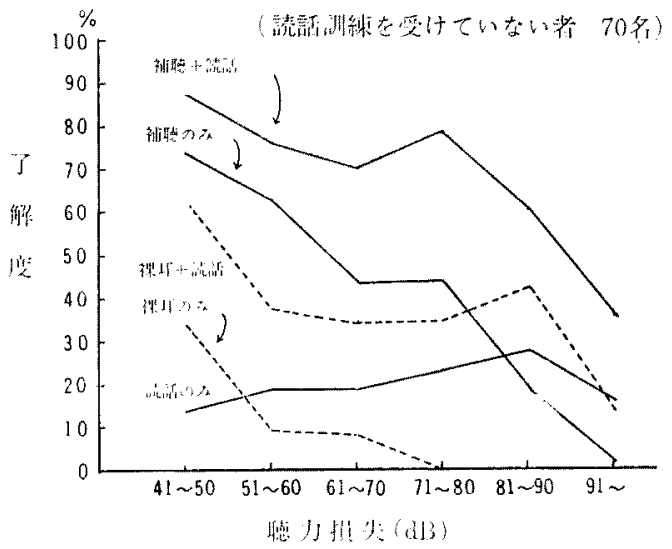

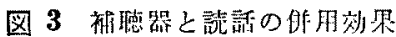

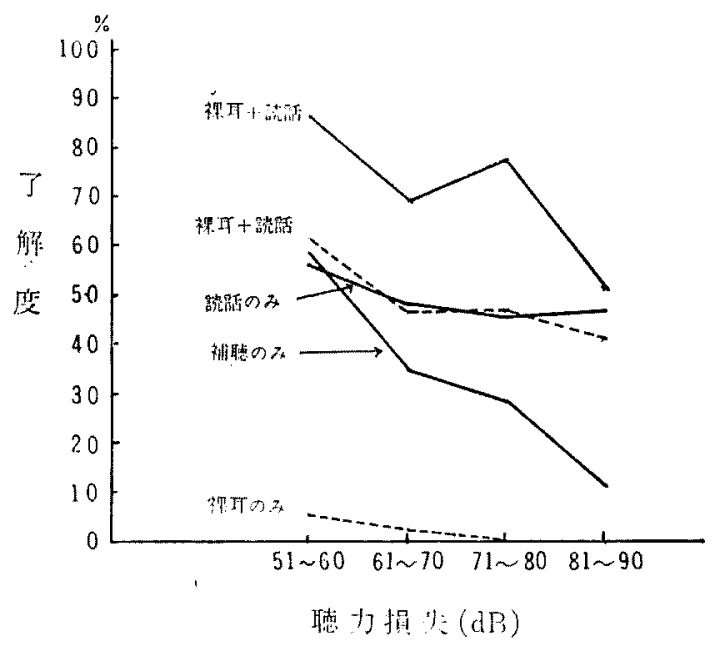

2 つの図に示す如く，補聴器と読話の併用成䌙も，全 体的に見ると，純音聴力損失の增大に伴って低下してい る. 更に，この併用成結を，読話や補聴器の単独使用胡 の成績之比校すると，聴力損失の少い者は，補聴成綨が 良く，聴力損失の大きい者は，読話成緥は良いが，併用 成續そのものが悪いと云う事が云える，従つて，併用成 縝は，聴力損失 $71 \sim 80 \mathrm{~dB}$ の所で，1つのピークをな し，この聴力損失程度の者が最も良い储用効果得てい ると云える。

次に, 補聴器単独と読話単独の成繢を比較すると, （図 2)の訓練を受けない者に私いては，榬力損失 81〜 $90 \mathrm{~dB}$ の左方で 2 つ曲線が 交叉している。これは，純 音聴力 $80 \mathrm{~dB}$ 以下では補聴成續が読話成績より良いが, 81dB を越觉ると読話成績の方が良くなる牙を示してい る. 即ち, $80 \mathrm{~dB}$ 以下の聴力損失者では，聪覚を主体以 読話は補助として使われて括り，81dB 以上の恥力提失 者では視覚を主体に，補聴器怔補助として使われている 牙学示与。

訓練を受けた赤のある者では，(四3）に示寸如く， 裸耳之読話の併用成績之読話単独成績を比較すると，2 つの曲線は殆んど重さなつた状態となつている，又，夫 今の平均值も， $48.3 \%$ と $51.4 \%$ で，大差がない，即ち， 裸耳を使っても殆んど差が生じない，更汇，補㯖器単独 成績は，聴力損失 51〜60dB の場合のみわつが范話 単独成續を上迴っている以外，読話単独成績より劣って いる。これ等の点より，明らかに訓練を受けた者の成績 はあくまで読話が主体をなしていると云える。

次に，語話単独，補聴単独及び併用の成緽の平均值を 訓練の有無別に示与と（表 14）の如くてある．読話訓 綝を受けない者では，併用成績は夫々の単独成績の和以 上になつているのに反し，訓絬を受けた者では和以下で ある。即ち万弓教育を受けた者の搠用效果は少い。

表 14 単独と甠用の比茭（\%)

\begin{tabular}{|c|c|c|c|c|c|c|}
\hline 剅 練 〉 & 讜 & 話 & 補 & 聴 & 併 & 用 \\
\hline 受けていない & & 0.0 & & 47.3 & & 73.3 \\
\hline 受けた & & 8.3 & & 33.4 & & 73.3 \\
\hline
\end{tabular}

第 5 節 語音聴力との関係

范話単独, 補聴器算独及び両者併用の成績を，被検者 の最良語音明膫度を参㚙して图示すると（困 4) の如く になる。この図に見る如く，読話成績は最良明瞭度の良 


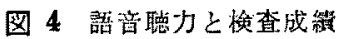

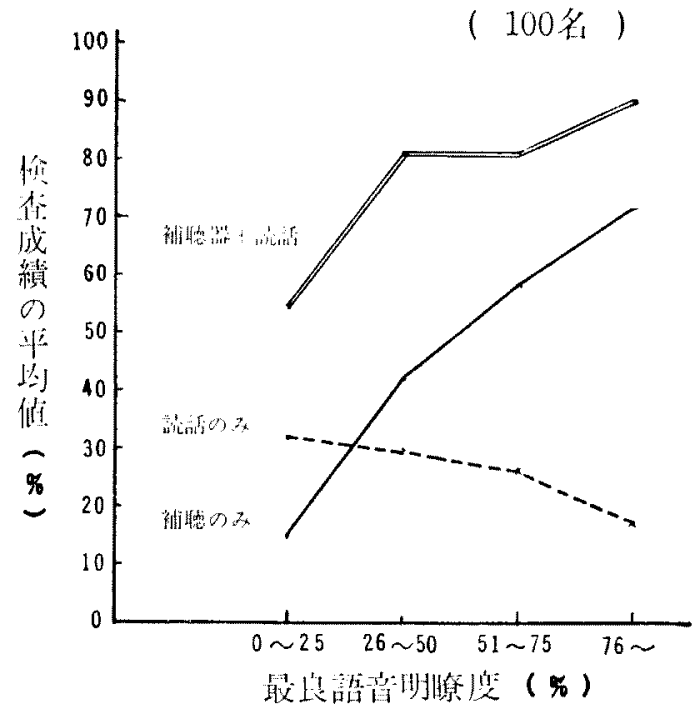

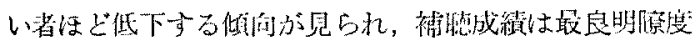
に上く一致している。併用成績は最良明瞭度 26〜50\% の肵で1つのビークななし，最も良い件用效果を得てい

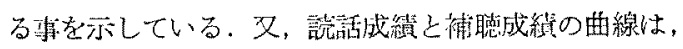
最良明膫度 $26 \%$ より左方で交叉しており，最良明膫蚁

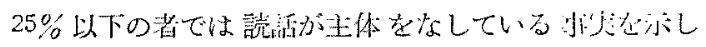
ている.

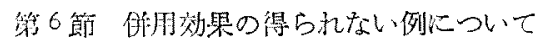

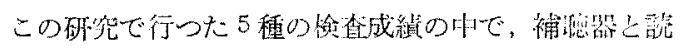

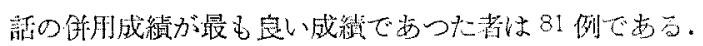

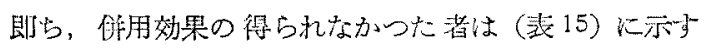

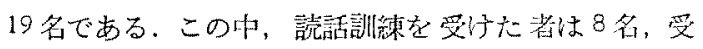
けなからた者は11名であるが，夫ふの全被倹者矿詨す る部合は，訓練学受けた者のうぶ多い，

又、（表 15）に示与通り，溒話訓練定受けた与のある

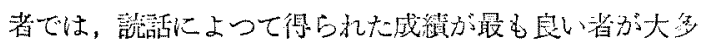

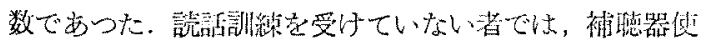

表 15 作用效果の得られない例

\begin{tabular}{|c|c|c|}
\hline 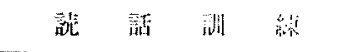 & 䚙 & 准 \\
\hline 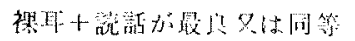 & 6 & 5 \\
\hline 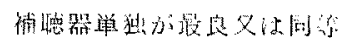 & 5 & 1 \\
\hline 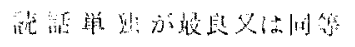 & & 2 \\
\hline 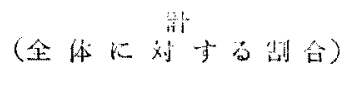 & $\left(15.7^{11}\right.$ & $\begin{array}{r}8 \\
(26.6 \%\end{array}$ \\
\hline
\end{tabular}

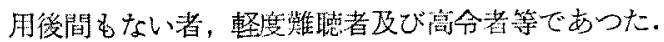

\section{第 6 草 紷括道ひに考按}

以上の娭查成績が

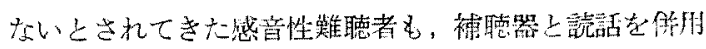

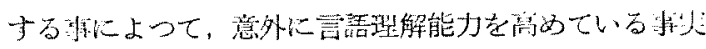
が明らかとなつた。

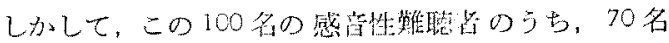

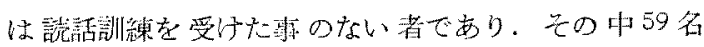

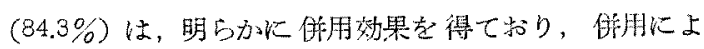

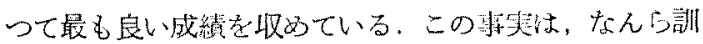

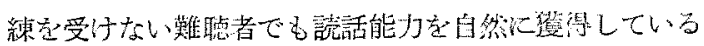

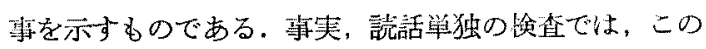
訓練を受けない者の $80 \%$ が，多かれ少かれ溒話成維を 得ていた。

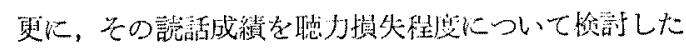
綃果，紽曋聴力 $90 \mathrm{~dB}$ 恋での者では，損失の增人に俳

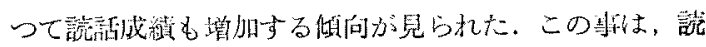

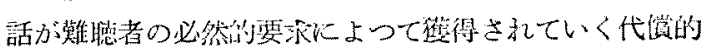

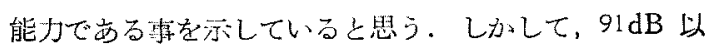

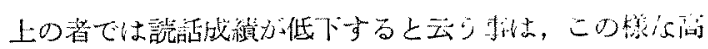

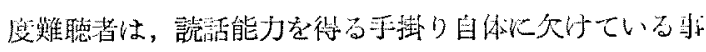
を示すものと䍐う。

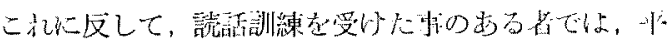

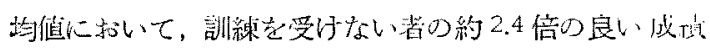

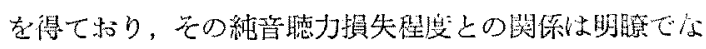

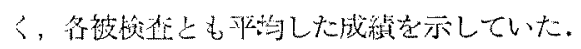

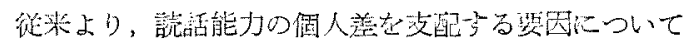

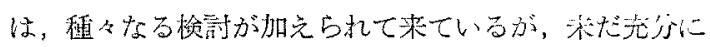

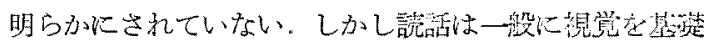

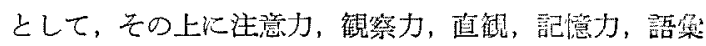

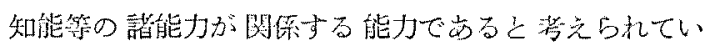
る. 久 Corinne M. Tatoul, Nitchie 等ま， はんのわ

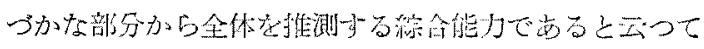

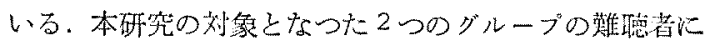
お゙いて，これ等の能力に差方あるとは教えられたい、む

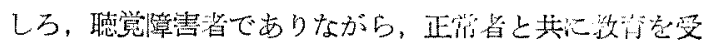

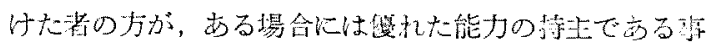
が考えられるので，2つのグループの読話成䊓の宾は，

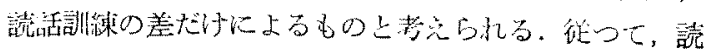

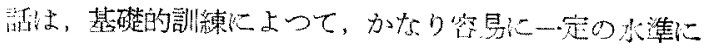

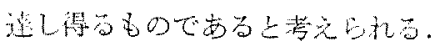

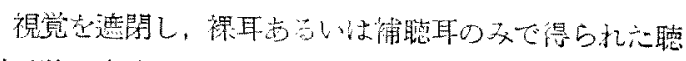

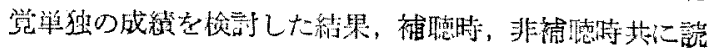


話訓練を受けない老より，受けた者が劣つている事が明

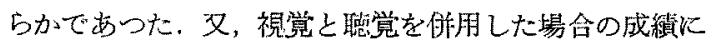

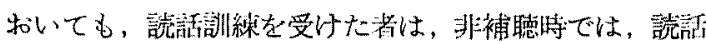
単独成縝と大垭なく, 補恥器を使用しても, 訓練を受け ない者に比して改善される度合は少なかった。このよう な事笑は，読話訓練を受けた者が残存聴力を充分に利用 していない雅を示するのである、これは，ろう学校と云 ら特殊な環筧に羁かれた難聴者が，聴覚を通して，言語 劣理解する習性を失つて行く事罢を証明していると云え る。か少意味に打いて，難聴者はろうと区別して教育 されるべきと思う。

本研觉においては，有意三音節用語を検查に使用した ので，談話訓練を受けた者には有利な結果が得られてい る。訓練を受けた諸では，最高 $88 \%$ の読話単独成績を 9 才の女の子が得て涉り，全体では訓練を受けない者の 約 2.4 倍の平沟値を示した。しかし，読話は単語の理解 ほど容易に単文や会話の理解はできないと云祅れてい る. Pauls や Pollack 等の硼究によ机ば，最もよく訓 練された場合でも，讜話だけで理解できる Speech は 35〜 55\%が限界であると述べている，従つて，悖覚障

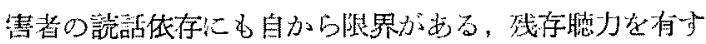

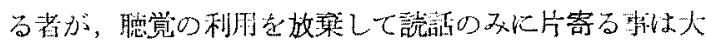

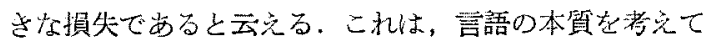
も当然事と云える。

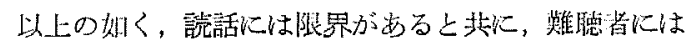
元来，婹覚に必限界があるのであるから，この二の限界

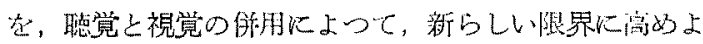

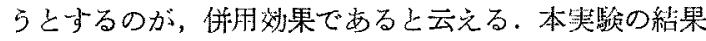
では，補聴器を使用している者の $81 \%$ 小゙，補暗器と境

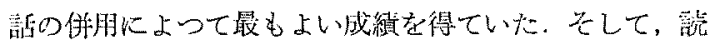
話訓練を受けた事のない者では，夫々算独使用時の成䅡 の和以上の成績が得られていた。

Hudgins に上れぱ，この併用効果は大脳皮質中枢の 綜合作用によつて得られるのであらうと述べている，即

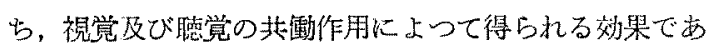
るので，ろう教育を受けた者の如く，視覚に依存しすぎ

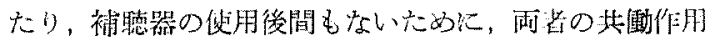
に㤨机ない者では併用効果が得られないての上判断され

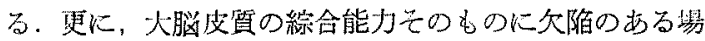
合毛搠用效果は得られないと考党られる。 Hudgins は， 50 才上上の老人に併用効果が見られないのは，末梢障

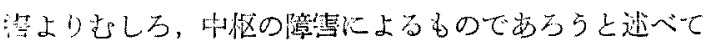
いる.
又, Pauls は，読話と補㯖は，夫今同し目的に问つて 独立しふ能力として働くのであるから，補悖器の使用に よつて，読話能力が低下寸る訝はないと述へている，徤 つて最も良い效果を得るためには，Berry 等が述へてい、

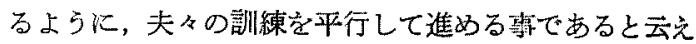
よう。

従来，感音性難聴者に対する補聴器適合の判定は語音

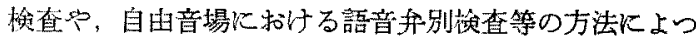
て行われて来た。 その結喿，感音性難㯖者の補聴効果は 余り期待できないものと考光られて, 補聴器は積極的に

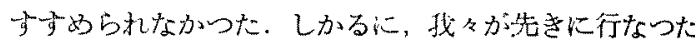
調查に上机ば，131 名の感音性難㯖者の俌㯖器使用経駼 者中 $21.1 \%$ の多数が常用者となり，使用中止したるのは 29\%に過ぎない事実が明らかとなつた。この事は，感 音性難聴者の場合，手術等の医療が聴力の改善に多く期 待できないために，補聴器が最終的手段となつていると

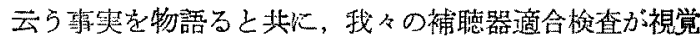

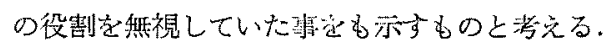

前述の如く，高度蜼聴者の場合，特飞㜔話剖練を受け なくとも，代僖的に読話能力を得ている者が多く，䘯臆

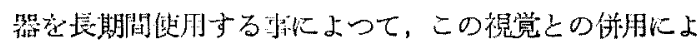
る予期以上の刘果を得る到が明らかとなつた。本梌查法 は，難㯖者の補聴効果のみならず，その䛃話能力をも松

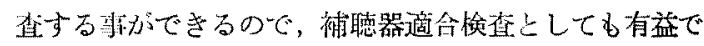
ある、又，補聴器を見に优用している渚に詨しては，視

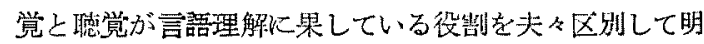

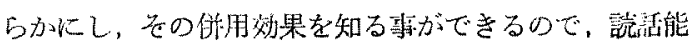
力の少る者にはその訓練の必要性を，又，残存聴力の程

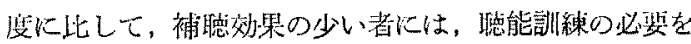
指摘する事ができる。 その際，本研究で示した100名の

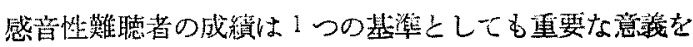
有するものと思う。

但し, 本研究では補聴器を現化使用している者を対象 としたので，補聴泇果の全く得られない者は含まれてい ない.

\section{第 7 章 結 語}

1) 補聴器の併用效果は, 対象者の $81 \%$ \%認められ, 特に平均聴力損失 $71 \sim 81 \mathrm{~dB}$ の者に鼠も著しい齐果が 見られた。

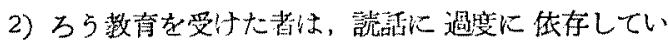
るため，聴賞の湖用が不充分な者が多く諗められた。

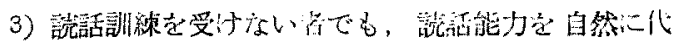
償的に蒦得しており，聴力損失 $80 \mathrm{~dB}$ 以下の場合は聴 
覚を主体に，てれ以上の場合は視觉を主体として言語を 理解している。

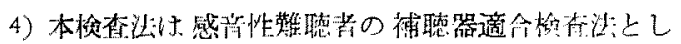
て有益でする。

\section{琶妾文献}

1) Mildred, F. Berry., Jon Eisenson: Spcech Disorder. p.tas, jto. 2) H. Nezby: Audiology, p. 3i 27. Davis: Hearing and Deafness; Marian, D., Pauls, M.A., "Speechreading"

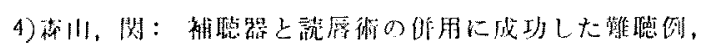

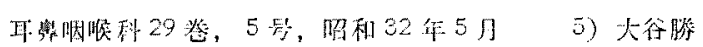

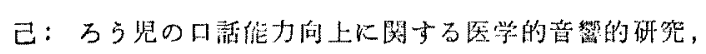

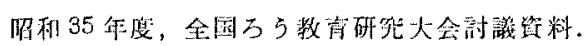

6)

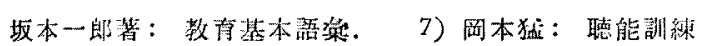

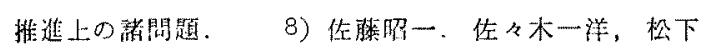

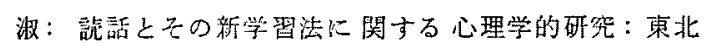

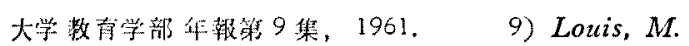
Dicarlo, and Raymond, Kataja: Analysis of the Utley Lipreading Test. J.S.H.D., 16, 226, 1951. 10) Corinne M. Tatoul, and G. Dan Danidson: Lipreading and Latter Prediction. J.S.H.D., 4, 178, 1961. 11) Hans, G. Furth: Visusl Paired-Associates Task with Deaf and Hearing Children. J.S.H.R.. 4, 172 , 1961. 12) Charles Hutton: Diegnostic Approch to Combined Technique in Aur.t Rehabilitation. J.S.H.D., 20, 1955. 13) Charles Hutton: Semidiagnostic Test Material for Aural Rehalilitation, J.S.H.D., 24, 319 20\%, 1959 14) Sumby, W.H., and Pollack, I.; Visual Combination to Speech Intelligibility in Nois. J.A.S.A., 26, $12 \sim 15.1954$. 15) Hudgins, C.V.,: Auditory-training: its Possibility and Limitation. Volta Review, 61, 33? 249 ,

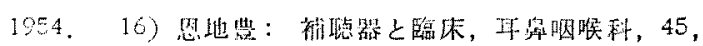

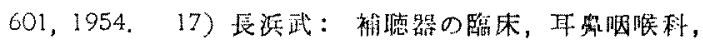
29 㷀 3 是, 炤和 32 年. 18) Jean Utley: A Test of Lipreading Ability. J.S.H.D. 11, 109 116. 1946.

痢を終るに当り，御指尊と御校閲をいたたいた堀

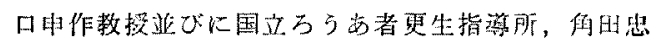
信愽士に心から感謝の意を装します。

本諭文の要旨は第63可日本耳粤㸶娭科学全総会に 和いて発表した。

（原䓟到着=昭和 38.5 .2 日） 